פקודת צבט ריטורית בבעיות תרגום של הקוראן הקדוש לעברית

של הצזרחצים היהודים השלשה

(רקנדורף - ריבלין - בן שמשי)

עוזר מורה

אחמד סעיד עביד

\title{
وجهة نظر بلاغية في مشاكل ترجمة القران الكريم الى العبرية
}

\author{
م.م. احد سعيد عبيد \\ كلية اللغات/ جامعة بغذاد
}

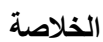

إن دراسة هذا البحث والغاية الرئيسية منه هو تسليط الضوء عل الأخطاء الترجمية الكبيرة للمستشرقين اليهود الثُاثة (ركندورف-

ريفلين- بن شمس) في ترجماتهم لمعاني القران الكريم رغم وضوح دلالات القران الكريم وإمكانية نقله إلى اللغة العبرية بوضوح،وجاء هذاء البحث أيضا لمعرفة قيمة ومكانة القران الكريم لاى اليهود،والذي يعتبر جوهر الدين والحضارة الإسلامية ـ وتتناول هذا البحث نقل صورة التحريف الواضحة للمستشرقين اليهود الثلاثة من خلال استخدامهم الألفاظ عبرية محرفة وتوضيح الرويا الاستشراقية المعادية للإسلام ، كما وتم تسليط الضوء على عدم التزام المترجمين الثلاثة بالعطف في النص الأصل للقران الكريم وتعددم في استخدام دقة الضمائز وعدم التزامهم بالتقديم والتأخير في النص العربي الأصل ، وكذلك أضاف كل من (ركندورف وبن شمس) عبارات هدفها الأساسي هو القول بوجود تأثير يهودي على القران الكريم ـ إن ترجمة معا ني القران الكريم للغة العبرية هو ليس لسد الفراغ الموجود في اللغة العبرية وفهم نص القران الكريم ، بل إن الهذف الرئيسي هو تأكيد القول بوجود تأثيرات توراتية ويهودية في نص القران الكرئ الكريم أولا وأخيرا .
\end{abstract}

\section{$\underline{\text { Abstract }}$}

The study of this research and its main purpose is to shed light on the linguistic errors of the three Jewish orientalists (Röndorf-Rivlin-Ben-Shams) in their translations of the meaning of the Holy Quran despite the clarity of the meanings of the Holy Quran and its possibility of being clearly translated into Hebrew. This research also attempts to reveal the status of the Holy Quran which is considered the essence of religion and Islamic civilization. This study deals with the transfer of the image of the clear distortion of the three oriental Jews through the use of distorted Hebrew words and clarification of the orientalist vision of anti-Islam. It highlightes the lack of commitment of the three translators in using conjunctions and pronouns as they are used in the original text of Quran. The three translators also do not stick to the original sequence of phrases and sentences as they are used in the Holy Quran. Moreover (Sundorf and Ben Shams) added phrases whose main purpose is to say that there is a Jewish influence on the Koran.

The translation of the Holy Quran into the Hebrew language is not to fill the gap in the Hebrew language and to understand the text of the Holy Qur'an. Rather, the main objective is to affirm the existence of Biblical and Jewish influences in the text of the Holy Qur'an .

\section{הקדמה}

הקראן הקדוש נחשב מהספרים החשובים ביותר למזרחנים שיצאו במחקרו ולנסות להבין בשפתו הערבית או על יד תרגומו לשפות רבות של העולם עד מספר השפות האלא היה בסביבות (דץ) השפה הרשמית ברחבי 
תרגומים אלה באו כמו תרגומים חלקיים של פסוקים או סורה .

והמחקר שלנו במחקר זה היא עיון ביקורתי למשמעיות של הקראן הקדוש בתרגומי היהודית סורת הפרה כדוגמה . היה למוד משליהם לצעוד חוקרים רבים הערבים כדי ללמוד על ההיסטוריה התרגומים של עברית למשמעות הקראן הקדוש ואיך להתמודד מתרגמים עם הטקסט המקורי . והתחילנו במחקר זה שלנו לימוד הפסוקים הביאה של יהודים של התרגומים למשמעות הקראן הקדוש. במונחים של המקביל ، כמו גם חיקור הבעייתי של תרגום פאות רטוריים בתרגומים אלה. החוקר בנושאים זות שמשפיעות בני ישראל כללי והיהודים במיוחד היא לעמוד על סגנון התענין המתרגמים היהודים לנושאים זות שמשפעיות להם ומתייחס אמונתם וספוריהם . כי המטרה העיקרית של המחקר זה היא לקבוע את השיטה תוכניות על פי תוכניות התרגום על פי התופעה של המזרחנות ועמדתה על האיסלאם בכלל ומהקראן בפרט מתוך לראות ברור בתחום זה כדי לתקו כל חטא כלולה של תרגומים זות ולכדי ליצור תרגום של עברית מקובלה למשמעות הקראן הקדוש.

\section{-}

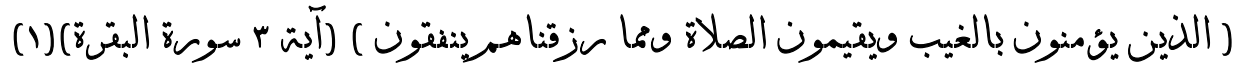

\section{- 1}

\section{( ומפזרים לאביונים ממה שנתתילהם ) ( )}

במקביל זה אנו מוציאים כי ( רכנדורף ) לא מחויב בהעביר בטקסט המקורי،אז עבר מקביל ( מפזרים ) על מושא ( ממה שנתתי להם ) בסוף הפיסוק בצורת גוף יחד־וזה אבד משמעות הגדול גם המתרגם בא במושה נמחק(לאביונים) והוא לא להזכיר על יד אחד מהפרשונים . נים לכן אנו רואים כי המתרגום הפר בסידור הפיסוק מצד אחד ובמשמעותיה מצד השני. כל כך מבחינתו תרגום של ( רכנדורף ) היתה חלש ולא מחויב בטקסט המקורי של הקראן הקדוש.

\section{Y}

ריבילן ( ומאשר חלקנו להם יפזרו ) (ז)

אנו מוצאים במקביל זה כי ( ריבילן ) שקד על סגנון העיקרי ושמר על מעביר ( חלקנו להם ) על הפעל

וגם הוא שקד על שם גוף גדלות ( ומאשר חלקנו להם יפזרו ) מבחינתנו אנו רואים תרגום של ( ריבילן ) היא מחויב ביותר והעדיף וקרוב מן הטקסט המקורי של הקראן הקדוש. 
( ( התרומים ממה שהענקנו להם ) ( )

אנו מוצאים (בן שמש) בתרגום הפסוק זה מעביר פועל ( התורמים ) על מושא ( ממה שהענקנו להם ) כלומר זה הוא אבד משמעות המעביר בטקסט העיקרי . גם אנו מוצאים בן שמש שמר על שם גוף הגדלות והוא לא הוסיף את מושא וגם המתרגם הזניח את מילה (1יה

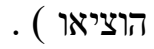
מבחינתנו אנו מוצאים תרגום בן שמש ( תרגום חסר ) למרות היא מעדיף מתרגום רקנדורף אבל בן שמש אבד חלק ממשמעות הטקסט המקו ، על כך תרגום ריבלין היא העדיף וקרוב מטקסט המקורי מבין התרגומים

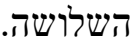

\section{-}

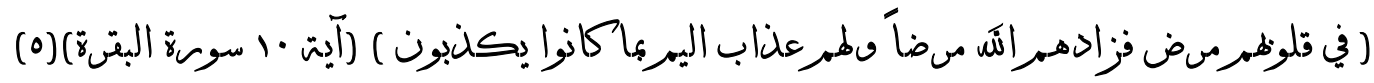

\section{1- תרגום רקנדורף:}

(דלי בקרב לב ، ואלוהים לא יגהה מהם את מזירם ולהם עונש גדול ، על אשר שקרו באל ) (ד) אנו מוצאים כי המתרגם ( רקנדורף ) שמר על מקביל ( חלי ) הוא זכר אותו במקרה הראשונה ، וגם חזר אותו אבל הוא הפר להטקסט המקורי בהגדיר השניה . גם הוא זכר מילת ( לב ) בצורה יחד בעוד היא (

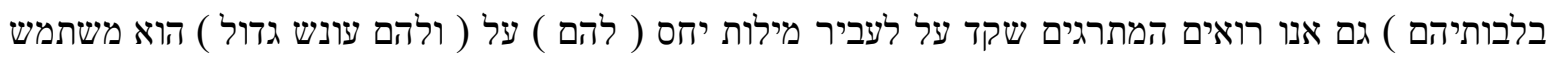
מקביל ( גדול ) בעברית חילופי על ( מכאיב ) זה נחשב מקביל חסר ממשמעות המקורי . אנו מצואים הוא משתמש מילת חסד ( ואלוהים ) במשפט הראשונה שונה למקורי . וגם הוא שונה מקביל ( חלי ) בא בפעם במילת

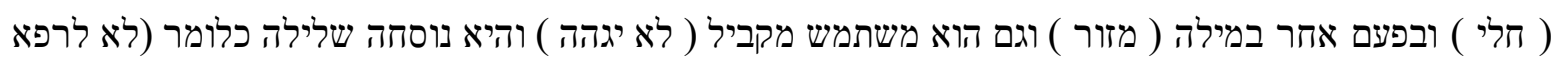

) (ומבחינתנו זה מקביל חלש ורחוק מהטקסט המקורי .

\section{ז- תרגום ריבילן:}

( חלי בלבותם ، ויוסף אלהים על חלים וענשם דאבה עקב אשר כזבו ) ( )

אנו מצאנו כי המתרגם (ריבילן) מחויב בטקסט העיקרי הוא אסף בלבותם) כמו הוא חמד להשתמש הפעל (ויוסף) מחסוד על החלק הראשון של המשפט ، גם הוא חמד להשתמש מקביל אותו במקרה השני. גם אנו רואים המתרגם לא שוקד על מעביר מילת יחס ( להם ) והשמיטו שלו וחלף אותו בשם גוף ( עונשם ) וזה אבד חלק ממשמעות המקורי . על כך אנו רואים ، תרגום ( ריבילן ) היתה תרגום חסר ולא מחויב במקורי ורחוק מטקסט העיקרי . ז - תרגום בץ שמש :

( ) ( אללה יוסיף להם על מחלת הכפירה שבלבותיהם עוד חולי עם עונש כבד על כזביהם ) 
אנו מצאנו בפסוק זה כי בן שמש מעביר ואחר וזה שונה לטקסט העיקרי של הקוראן הקדוש והוא מעביר בתחילת הפסוק ( אללה יוסיף להם ) ואחר (שבלבותיהם עוד חולי ) ועושה בין פעל לבין פועל ( חולי ) וגם המתרגם בן שמש בא בביטוי ( חולי ) במקרה הראשון לדעת והוא שונה למקורי ובמקרה השניה בלתי מידע כמו המקורי • הוא ההפך של מה עשה ( רקנדורף וריבילן ) כמו גם מצאנו שהמתרגם שמט מילות יחם ( להם ) כמו

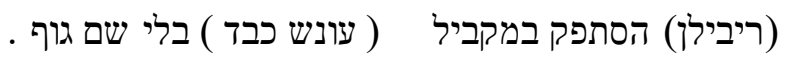

לכן נחשב תרגום (בן שמש )רע ביותר מבין המתרגמים שהוא הפר בטקסט והיה לא מחויב בסדור המקורי . אז מבחינתנו אנו מוצאים כי תרגום ( רקנדורף ) היא היחיד שחמדה את מעביר ( מילות יחס ) בחלק השני של ריל הפסוק ומבחינתנו אולי התרגום המוצעה וקרוב של הטקסט המקורי של הקוראן הקדוש היא ( בלבותם יש חלי ויוסף אלוהים על חולים ולהם עונש מכאיב ואבה עקב אשר כזבו ) .

\section{: -}

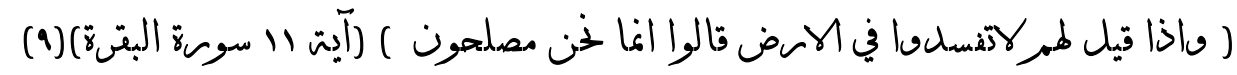

\section{: 1}

(1) (יאם יאמר להם : אל תשחיתו בארץ • יאמרו : הן כנים אנחנו ) אנו רואים כי ( רקנדורף ) בהמקביל זה לא מחויב בנוסחה הקצר ולהחליף שלה בנוסחה חדשותי ، כמו המתרגם לא מחויב להעביר שם גוף ( אנחנו ) אבל אחר שם גוף בסוף המשפט ، וזה הפר למשמעות הקצר ، והמעביר. אז הוא לא מחויב בטקסט המקורי של הקוראן .

\section{: תרגום ריביללן}

(וכי יאמרו אליהם:אל תשחיתו על הארץ‘ואמרו:הלא עושי הישר אנחנו)(1') בתרגום הפיסוק זה · אנו מוצאים כי המתרגם ( ריבילן ) השתמש סגנון השאלה ( הלא ) ונוסחה זו מחייבת את התשובה ב (כן ) בניסיון מאותו להבין משמעות הקצר של טקסט העיקרי ، אבל הוא הפך את אפן המשפט לאפן השאלה במקום ממשמעות הקצר וגם אחר שם גוף כמו עשה (רקנדור) גם אנו מוצאיים (ריבילן ) מעביר המקביל ( הישר ) על שם גוף . אז אנו רואים תרגום זה הפר למשמעות הטקסט המקורי של הקוראן הקדוש.

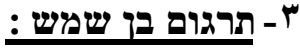

(כאשר מבקשים מהם לא לחרוש מזימות ולא לעורר מדנים בארץ הם עונים אנו רק מיגשבים סכסוכים ) 
אנו מוצאיים בתרגום זה כי( בן שמש ) מחויב בנוסחת הקצר ( אנו רק מיישבים ) כלומר ، זה חמד את

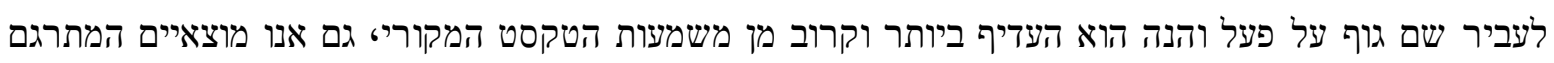
חטא במשמעות הרפורמה אשר הפך של השחיתות וגם הוא השתמש נוסחה (ישב סכסוכים ) וזה מקביל לא נכון ורחוק מהטקסט המקורי של הקוראן. אז המקביל ששתמש אותו ( ריבילן ) ( עשה הישר ) הוא העדיף וקרוב למובן המקורי •ומבחינתנו אנו רואים צריך תיקון מקביל ( בן שמש ) אל ( ואנו רק עושי הישר ) או התיקון להיות בסוף הפסוק של (ריבילן)، ( הלא אנו רק עושי הישר ) וזה הוא העדיף .

\section{-}

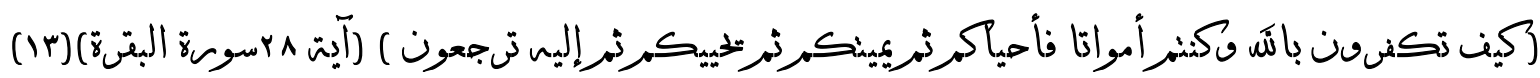
ו - תרגום רקנדורף:

(איך תבגדו באל פגרים מתים הייתם ، הוא החיה אתכם ، הוא ימיתכם וישוב ויחיה אתכם ، אז תשובו

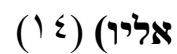
בפיסוק זה، אנו מוצאנו כי המתרגם ( רקנדורף ) בהמקביל זה לא מחויב בטקסט המקורי של הקוראן הקדוש הוא בנה הפועל לידוע כאשר עושה הפעול הם אותהם ( אז תשובו אליו ) כמו אנו רואים המתרגם מעביר את פעל על מלות יחס ( תשובו אליו ) וזה אבד סימנים קודמים שהבורים על תופעות אלה מבחינת הרטורים. וזה מאשר בכווינה של מתרגם להסתמך על משמעיות ביותר רחוק ממשמעות המוות הראשון. גם אנו מוצאנו המתרגם השתמש המקביל ( פגרים מתים הייתם ) והנה לא לקח בחשבון החבור ב(פ) ומה בינהם מן הבדל במובן כי המתרגם הסתמך על הסגנון העבריתי . לכן אנו רואים תרגום ( רקנדורף ) היתה לא מחויב בטקסט המקורי של הקוראן . וקצר על משמעותו.

\section{ץ - תרגום ריבילן:}

(איכה תכחשו באלהים ואתם הייתם מתים ויחיה אתכם ושב והמיתכם ושב וחיה אתכם ואליו תושבו ) אנו מוצאיים שהמתרגם (ריבילן) בתרגם הפסוק זה שמר על מעביר של מילות יחס (ואליו תושבו) וגם הוא מחויב למשמעות בנייה לבלתי-נודע (תושבו) של הפעל ( הושב ) גם המתרגם חמד ולקח בחשבון שלו השתמש הנכון של ( מילות חבור ) והוא השתמש (ו) בעברית במקום (פ) בעברית (ויחיה) כמו אנו רואים כי המתרגם השתמש (ו) ופעל (שב) מקביל (אז) בערבית ،כדי לציין את הרפיון באירוע. 
והוא הסתמךעל משמעות הקרובה למות במקרה הראשון כי הם הזרע ברחם.

ז- תרגום בץ שמש

(כיצד תכפרו באללה ؟ אם הייתם חומר חסד - חיים והוא נפח בכם רוח חיים? האם לא יביא עליכם את המוות כשתגיע שעתכם ושוב יקים אתכם לתחייה כשתוחזרו אליו) (ד (1) אנו מוצאים בתרגום( בן שמש ) של הפיסוק זה. הוא לא מחויב במשמעות העביר•אז אחר(מילות יחס) אחרי הפעל (כשתוחזרו אליו ) אבל המתרגם מחויב לבנייה לבלתי - נודע ( תוחזרו ) גם אנו רואים בן שמש שמר על משמעות המות כמו חסר החיים (האם הייתם חומר חסר - חיים) אז הנפח בחיים ( והוא נפח בכם רוח חיים ) גם אנו מוצאנו (בן שמש ) לא מחויב בסגנון הטקסט המקורי מבחינת ( ו החבור ) הוא שמר על ( ו חבור ) ב (פ)בערבית ( והוא נפח בכם רוח חיים ) ואחר כך הוא הפך הנוסחה מחדשות לנוסחה השאלה . אז אנו רואים בן שמש מחויב במשמעות הרפיון ( ושוב יקים ) לכן נחשב תרגום בן שמש תרגום חסר מן משמעות הטקסט המקורי והמתרגם לא מחויב בסגנון הטקסט העיקרי של הקוראן הקדוש. באופן כללי מבחינתנו נחשב תרגום ( ריבילן ) היא העדיף ומדויק ביותר וקרוב מהטקסט העיקרי של הקוראן הקדוש.

\section{-}

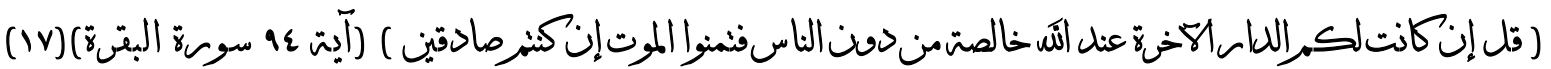

\section{ו - תרגום רקנדורפ:}

( אמור אליהם : אם תחפצו לבקר בהיכל די מותכם מפורדים מכל בני האדם ، בחרו במות אם כנים אתם)

אנו מוצאיים בתרגום הפסוק זה של ( רקנדורף ) במקביל זה בא (אם תחפצו לבקר בהיכל די אחרי מותכם) ואנו לא יודעים מה הוא (היכל) אשר מדבר עליו המתרגים (רקנדורף) של פסוק זה . ובמיוחד הפסוק זה ברורה בדבור על החיים לאחר המות • מה פירוש הנה לגן כפי אמרו הפירשונים . אנו מוצאים כמו כי המתרגם שבש את משמעות הפסוק מצד אחד ומצד הוא העביר את סגנון המשפט שמני אל משפט בפועל שהיתה בטקסט המקורי (אם כנים אתם) בהתרגום זה להיות הפסוק אבד משמעות המעביר של חדשות על מופעיל . כמו המתרגם שמט את משמעות (אם תחפצו לבקר בהיכל די אחרי מותכם)،מבחינתנו אנו רואים המתרגום (רקנדורף)הפר למשמעות הטקסט המקורי ، גם הוא הוסיף את תכונות יהודיים בהזכירו (בהיכל די) וזה מושג יהודי. 


\section{ץ - תרגום ריבילל :}

(אמור הן אם יהיה לכם לבדכם מעון האחרית את אלהים כלו כלו ולא לאיש אתכם ، כי עתה התאור למות

אם אמת תדברו) (19)

אנו מוצאיים כי המתרגום ( ריבילן ) שקד על מעביר והאחיר כמו בטקסט המקורי של הקוראן הקדוש. וזה נחשב הבנת את המתרגם למשמעות של פסוק . מבחינתנו אנו רואים כי תרגום של ( ריבילן ) לפסוק זה היתה תרגום טובה ומחויב בטקסט המקורי של הקראן הקדוש.

\section{ז - תרגום בן שמשש:}

(ועוד אמור להם : האם רק לכם בלבד ، ולא לכל בני האדם ، מיודע העולם - הבא אצל אללה ، הרי אם

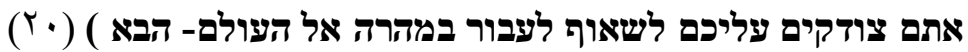
אנו רואים המתרגם (בן שמש) במשך תרגומו לפסוק זה •שנה סגנון תנאי (אם יהיה לכם לבדכם) אל סגנון שאלה (האם רק לכם) וזה הפר למשמעות הטקסט המקורי כי פסוק זות נחשב בתגובה על מה הם אמרו או חושבו בו בעבר . גם אנו רואים הפסוק זה באת כדי להכפישהם בסגנון דרישת (הרי אם אתם צודקים עליכם לשאוף לעבור) •

מבחינתנו המתרגם בן שמש הקל מן חשיבות את פסוק בגלל הפסוק קשורים ליהודים . גם אנו רואים המתרגם לא מחויב בסדור הטקסט המקורי של הקוראן הקדוש והוא שמר על מעביר (לכם) אבל אחר לזכור (מיודע העולם - הבא אצל אללה) אחרי דברי אלהים (ולא לכל בני האדם). מבחינתנו אנו רואים כי המתרגם בן שמש לא מחויב למעביר כנראה לנו . הוא התערב של טקסט במעביר ועיכובים וזה הפר למשמעות הטקסט המקורי . ובמשמעות מעביר החדש (לכם) ואחר כך באת תרגום בן שמש לא מחויבה במקורי ואבד לחלק של המובן. על כך אנו חושבים כי תרגום של (ריבילן )היא העדיף וקרובה מן הטקסט העיקרי של הקוראן הקדוש. המסקנות ו - המתרגמים השלושה יצאו מהטקסט המקורי של הקוראן וזה נחשב שהם לא מחויבים בטקסט המקורי מבחינת המקביל הרטורית، למרות להסביר משמעות של הקוראן ואפשר עבור שלו ללשון העברית בהסביר . ז - המתרגמים לא יכולים בהתמודדות עם הטקסט הקוראני מבחינת המקביל מתוך השתמשו מקבילים חסרים כמו במקורה של רקנדורך ובן שמש. ז- המתרגמים לא מחויבים ב(ו) החבור ،אז רקנדורך ובן שמש שמטו (ו) החבור בפסוק ביותר. צ - המתרגמים כמו היו לא מחויבים בהעביר והאחיר מבחינת הרטוריים של הטקסט המקורי. וגם היו לא מחויבים 
0 - המתרגמים הוסיפו מילים מטרה מזה לומר קיומה של ההשפעה יהודית על הקוראן . 7 - כמו כמה המתרגמים הם שינו הטקסט העיקרי של קוראן כדי להסכים עם חזון המזרחן אנטי -איסלאם . ע - כל זה מבטיח לנו את חסר שפה העברית מול כוח ורטוריים השפה הערבית . וזה מסביר אין אפשר השפה העברית להבין משמעות הטקסט הקראני ומשמעותו. 1 - המתרגמים השלושה רצו להגיעו רעיון מתוך התרגום זותי הוא קיום אפקט המקראי ויהודי בטקסט של קוראן וכי הקוראן הוא ציטוט מהתנך. 9 - לכן כי המטרה העיקרי של המחקר הוא המטרה של המזרחן בראש ובראשונה. הערות שולים

$$
\text { 1ـ القران الكريم ، صץ . }
$$

§- רקנדורף ، תרגום הקראן ، גרמניה ، ליבזג ، 1Avo ، עם ז.

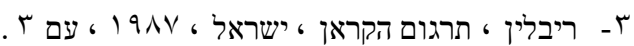
ז'- בן שמש • תרגום הקראן • תל אביב 19v1 ، עם ז.

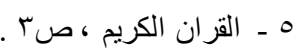

ז- רקנדורף ، תרגום הקראן • גרמניה ، ליבזג ، 1Nvo ، עם

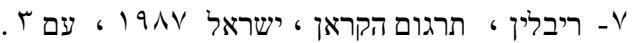
ג- בן שמש • תרגום הקראן • תל אביב ، 19ע ، עם •1 - 11.

$$
9 \text { ـ القران الكريم ، صץ . }
$$

• ו- רקנדורף ، תרגום הקראן ، גרמניה ، ליבזג ، 1ו- ריבלין ، תרגום הקראן ، ישראל ، 19Av ، עם ז1. זו- בן שמש ، תרגום הקראן ، תל אביב ، 19v1 ، עםץ ז1 اـ القران الكريم ، صه .

צו רקנדורף ، תרגום הקראן ، גרמניה ، ליבזג ، 1Nvo ، עם ז. 10- ריבלין ، תרגום הקראן ، ישראל ، 19Av ، עם ז. ז1 - בן שמש ، תרגום הקראן ، תל אביב ، 19v1 ، עם

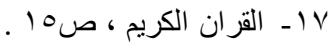

11- רקנדורף ، תרגום הקראן ، גרמניה ، ליבזג ، 1Nvo ، עם ؛ . 19- ריבלין ، תרגום הקראן ، ישראל ، 191V ، עם ؛ . •r- בן שמש ، תרגום הקראן ، תל אביב ، 194ג ، עם ؛. 
ז- אבן שושן • אברהם • המלון החדש • הוצאת קריאת ספר בעיים • הוצאת ירושלים • • 19 .

ז- אילון •דוד ، מלון ערבי- עברי ، הוצאת ירןשלים • $19 \leqslant$ צ - בן שמש • תרגום הקראן בעברית • הוצאת תל אביב ، 19v^ .

•- יחזקיל ، קוגמן • מלון עברי- ערבי לשפה העברית • הוצאת תל- אביב ، •19v . ד- שגיב • דוד ، מלון עברי- ערבי לשפה העברית בת - זמננו הוצאת ירושלים ،1985 .

191v، ריבלין •תרגום הקראן בעברית • הוצאת ישראל - v - - רקנדורף ، תרגום הקראן בעברית • הוצאת גרמניה ، ליבזג INvo. 